\title{
DNA-DOPE-gemini surfactants complexes at low surface charge density: from structure to transfection efficiency
}

\author{
Lukáš Hubčík ${ }^{1}$, Dominika Galliková1, Petra Pullmannová1,2, Lubica Lacinová3,4, Zdena Sulová ${ }^{3}$, \\ Mária Hanulová ${ }^{5}$, Sergio S. Funari ${ }^{6}$, Ferdinand Devínsky ${ }^{7}$ and Daniela Uhríková ${ }^{1}$ \\ ${ }^{1}$ Department of Physical Chemistry of Drugs, Faculty of Pharmacy, Comenius University in Bratislava, Odbojárov 10, \\ 83232 Bratislava, Slovakia \\ ${ }^{2}$ Department of Inorganic and Organic Chemistry, Faculty of Pharmacy in Hradec Králové, Charles University in Prague, \\ Heyrovského 1203, 50005 Hradec Králové, Czech Republic \\ ${ }^{3}$ Institute of Molecular Physiology and Genetics, Center of Biosciences, Slovak Academy of Sciences, Dubravska cesta 9 , \\ P.O.BOX 63, 84005 Bratislava, Slovakia \\ ${ }^{4}$ Faculty of Natural Sciences, University of Ss. Cyril and Methodius, Nám. J. Herdu 2, 91701 Trnava, Slovakia \\ ${ }^{5}$ Microscopy Core Facility at the Institute of Molecular Biology, Ackermannweg 4, 55128 Mainz, Germany \\ ${ }^{6}$ HASYLAB at DESY, Notkestr. 85, D-22607 Hamburg, Germany \\ ${ }^{7}$ Department of Chemical Theory of Drugs, Faculty of Pharmacy, Comenius University in Bratislava, Odbojárov 10, 83232 \\ Bratislava, Slovakia
}

\begin{abstract}
DNA condensation, structure and transfection efficiency of complexes formed by gemini surfactants alkane- $\alpha, \omega$-diyl-bis(dodecyldimethylammonium bromide)s (CnGS12, $n=3,6$ and 12 is the number of alkane spacer carbons), dioleoylphosphatidylethanolamine (CnGS12/DOPE $=0.3 \mathrm{~mol} /$ mol) and DNA at low surface charge density were investigated through different techniques. Small angle X-ray diffraction showed a condensed lamellar phase with marked dependence of DNA-DNA distance on (+/-) charge ratio. High ionic strength of hydrating medium screens the interaction DNA - CnGS12/DOPE and complexed DNA represented maximally 45-60\% of total DNA in the solution as derived from fluorescence and UV-VIS spectroscopy. The in vitro transfection efficiency of CnGS12/DOPE liposomes on mammalian HEK 293 cell line was spacer length-dependent. C12GS12/DOPE/DNA complexes exhibited the best transfection efficiency ( 18\% GFP-expressing cells relative to all viable cells) accompanied by $\sim 89 \%$ cell viability.
\end{abstract}

Key words: Gemini surfactants - Lipoplexes - Small angle X-ray diffraction — Fluorescence spectroscopy - Transfection

\section{Introduction}

A fundamental requirement of gene therapy is to deliver gene-based therapeutics into target cells for specific gene

Electronic supplementary material. The online version of this article (doi: 10.4149/gpb_2017042) contains supplementary material, which is available to authorized users.

Correspondence to: Lukáš Hubčík, Department of Physical Chemistry of Drugs, Faculty of Pharmacy, Comenius University in Bratislava, Odbojárov 10, 83232 Bratislava, Slovakia E-mail: hubcik@fpharm.uniba.sk targeting with minimal cytotoxicity. The most effective transfection agents are viruses (Robbins and Ghivizzani 1998); however, serious safety concerns are associated with their clinical use (Verma 2000). Non-viral vectors offer many advantages including absence of viral components and low immunogenicity. They are less expensive, easily manufactured, more flexible with regard to the size of the DNA being transferred, and can be readily altered to form different combinations depending on the intended treatment. In recent years a large spectrum of different non-viral transfection agents has been developed. Cationic liposomes (CL) consisting of cationic lipid (Felgner et al. 1987; Hung et al. 2005; Wasungu and Hoekstra 2006; Caracciolo et al. 
2007) or cationic surfactant with or without helper lipid (Bell et al. 2003; Badea et al. 2005; Khan et al. 2012; Perrone et al. 2013) have been widely studied as potential vectors for in vitro and in vivo gene delivery.

DNA used in the cationic lipid mediated gene delivery represents a linear polyanion. Its interaction with $\mathrm{CL}$ is spontaneous and results in the formation of DNA-CL complexes called lipoplexes. Negatively charged phosphate fragments of DNA create binding sites for lipoplex formation due to electrostatic interactions. Neutralization of the negative charge of DNA by CL results in the condensation of DNA, allowing thus a close approach of DNA chains. In this packing, DNA is protected against degradation in plasma (Rolland 1998). The interaction is endothermic and rapid (Barreleiro et al. 2000), and takes place during the aggregation process, while both phospholipid and DNA undergo a complete topological transformation into compact quasi-spherical particles with an ordered internal structure (Gershon et al. 1993; Koltover et al. 1999). The complexes DNA-CL have sizes in the range of hundreds of nanometers, and are largely taken up by cells in the process of endocytosis (Zabner et al. 1995). However, currently available lipoplexes are generally less efficient in delivering DNA and in initiating gene expression than their viral counterparts (Schmidt-Wolf and Schmidt-Wolf 2003; Djurovic et al. 2004). Therefore more research on the correlation between transfection efficiency and various characteristics of the lipoplexes is needed ( $\mathrm{Li}$ and Huang 2006; Rao and Gopal 2006; Zuhorn et al. 2007; Donkuru et al. 2010).

Gemini surfactants (GS) consists of two hydrophobic chains and two ionic or polar groups linked by a spacer. They were introduced by the group of Kirby (Camilleri et al. 2000; Kirby et al. 2003) as promising transfectors forming complexes with DNA. Since then, a large variety of GS structures has been used for gene delivery (Bombelli et al. 2005; Kumar et al. 2010; Donkuru et al. 2012; Cardoso et al. 2015; Pietralik et al. 2015; Zakharova et al. 2016). One of the most studied type of GS are alkane- $\alpha, \omega$-diyl-bis(alkyldimethylammonium bromide)s (CnGSm, where $n$ is the number of spacer carbons and $m$ is the number of carbons in the alkyl chains). CnGSm proved to have a powerful bactericidal activity (Imam et al. 1983; Devínsky et al. 1985) with the correlation between their structure, activity and critical micelle concentration studied in further details (Devínsky et al. 1987; Hirata et al. 1995). CnGSm have been shown to be powerful plasmid curing agents (Belicová et al. 1995), and were used to increase the efficiency of DNA transfer into bacterial cells (Horniak et al. 1989). Nevertheless, pure DNA-CnGSm complexes exhibited only low in vitro transfection efficiency (Fisicaro et al. 2005; Foldvari et al. 2006). The presence of helper lipid DOPE has been found crucial to increase the transfection efficiency (Foldvari et al. 2006). These authors reported the highest transfection activity in vitro for CnGSm compounds with the spacer of three carbons (Foldvari et al. 2006; Wettig et al. 2007). GS with short spacers were reported to have enhanced transfection activity also by other authors (Bombelli et al. 2005; Fisicaro et al. 2005; Cardoso et al. 2011; MuñozÚbeda et al. 2012).

The structure and polymorphic behaviour of CnGSm/ neutral phospholipid/DNA complexes at various composition and temperatures have been studied by our group systematically (Uhríková et al. 2002, 2005; Pullmannová et al. 2008). The microstructure of lipoplexes formed by CnGS12, 1,2-dioleoyl-sn-glycero-3-phosphoethanolamine (DOPE) and DNA was studied in detail in our previous work (Pullmannová et al. 2012b) in which the lipoplexes were hydrated by the solution of $150 \mathrm{mM} \mathrm{NaCl}$. We have found that at physiologically relevant ionic strength of aqueous medium the microstructure of lipoplexes can be affected by the way of their preparation (Pullmannová et al. 2012a).

In the present work, we focused our attention on the role of the spacer length in transfection efficiency, keeping low surface charge density of CnGS12/DOPE liposomes. In our study CnGS12 with $n=3,6$ and 12 were selected. Small angle X-ray diffraction (SAXD) was employed to examine the structure of lipoplexes. The ability of CnGS12/DOPE liposomes to condense DNA molecule was studied using fluorescence and UV-VIS spectroscopy. The effect on cell viability and transfection efficiency was tested on the cell line derived from human embryonic kidney epithelium (HEK 293). Plasmid encoding enhanced green fluorescence protein (pEGFP) was used as a fluorescent reporter.

\section{Material and Methods}

\section{Preparation of cationic liposomes}

Alkane- $\alpha, \omega$-diyl-bis(dodecyldimethylammonium bromide)s (CnGS12, number of spacer carbons $n=3,6$ and 12) were prepared as described in Imam et al. (1983) and purified by manifold crystallization from a mixture of acetone and methanol. 1,2-dioleoyl-sn-glycero-3-phosphoethanolamine (DOPE) (Avanti Polar Lipids, Inc., Alabaster, Alabama) and CnGS12 were dissolved in chloroform and mixed to obtain a lipid mixture with desired molar ratio CnGS12/DOPE. Lipid mixtures were dried under a stream of gaseous nitrogen and the residue of chloroform was removed under vacuum. The dried mixture was hydrated with a $150 \mathrm{mM} \mathrm{NaCl}$ solution or Opti-MEM medium (Gibco Life Technologies Co.), respectively, and homogenized (by vortexing and freezingthawing cycles) until an opalescent multilamellar liposome dispersion was created. Unilamellar liposomes were prepared by extrusion of multilamellar liposomes through a polycarbonate membrane with pores of $100 \mathrm{~nm}$ diameter. 
Preparation of DNA solution

The solution of DNA was prepared by dissolving herring testes deoxyribonucleic acid (HT DNA) (Sigma Chemicals Co., St. Louis, Missouri) in $150 \mathrm{mM} \mathrm{NaCl}$ solution or in Opti-MEM medium, respectively. The precise value of DNA concentration was determined spectrophotometrically (Hewlett Packard 8452A Diode array spectrophotometer), according to: $c_{D N A}=A_{260} \cdot 47 \times 10^{-6}(\mathrm{~g} / \mathrm{ml})$, where $A_{260}$ is the absorbance at the wavelength $\lambda=260 \mathrm{~nm}$. The purity of DNA was checked by measuring the absorbance $A_{\lambda}$ at $\lambda=260$ and $280 \mathrm{~nm}$. We have obtained the value of $A_{260} / A_{280}=1.79$.

\section{Small angle X-ray diffraction}

The samples for SAXD studies were prepared by mixing $10 \mathrm{mg}$ of CnGS12/DOPE liposomes (CnGS12/DOPE = $0.3 \mathrm{~mol} / \mathrm{mol}$ ) hydrated with Opti-MEM medium with HT DNA solution prepared in Opti-MEM at charge ratios CnGS12/DNA $=0.5-3(+/-)$. After mixing cationic liposomes with DNA a precipitate was created spontaneously. The samples were mixed with $1.5 \mathrm{ml}$ DMEM (Dulbecco's modified Eagle's medium) to attain final volume of $2.5 \mathrm{ml}$ for each sample. The samples were stored at $2-6^{\circ} \mathrm{C}$ and they were shortly centrifuged before the measurement. The supernatant was used to determine the efficiency of CnGS12/DOPE in DNA binding via UV-VIS spectrometry. The binding efficiency was expressed as a difference between the total volume of DNA used for the lipoplex formation and the DNA volume fraction in the supernatant (unbound DNA). The light scattering on supramolecular aggregates was corrected as described in Lengyel et al. (2011).

SAXD experiments were performed at the soft condensed matter beamline A2 at HASYLAB at the Deutsches Elektronen Synchrotron (DESY) in Hamburg (Germany) or at SAXS beamline at Elettra Syncrotrone Trieste using a monochromatic radiation of wavelength $\lambda=0.15 \mathrm{~nm}$. The sedimented precipitate with a few drops of bulk solution was enclosed between two Kapton windows of the sample holder for X-ray diffraction or in $1 \mathrm{~mm}$ capillaries. The patterns were recorded using a 2D Mar CCD detector. The raw data were normalized in respect to the incident beam intensity. The SAXD patterns were calibrated using rat tail collagen (Roveri et al. 1980) or silver behenate (Huang et al. 1993). Each diffraction peak of SAXD region was fitted with a Lorentzian above a linear background using the PeakFit software.

\section{Fluorescence spectroscopy}

Fluorescence measurements were performed at the Fluoromax 4 spectrofluorometer (Horiba Jobin Yvon, France) using ethidium bromide (EtBr) (Merck, Darmstadt, Germany) as a fluorescent probe. Stock solution of EtBr was prepared by dissolving EtBr in $150 \mathrm{mM} \mathrm{NaCl}$. EtBr was mixed with $\mathrm{HT}$ $\mathrm{DNA}$ at $\mathrm{DNA} / \mathrm{EtBr}=6 \mathrm{~mol} / \mathrm{mol}$ molar ratio. After $5 \mathrm{~min}$ utes the mixture of unilamellar CnGS12/DOPE liposomes $(\mathrm{CnGS12} / \mathrm{DOPE}=0.3 \mathrm{~mol} / \mathrm{mol} ; n=3,6$ and 12$)$ was added to DNA labeled with the intercalated dye. At last $150 \mathrm{mM}$ $\mathrm{NaCl}$ was added to prepared mixtures to obtain final volume $3000 \mu \mathrm{l}$. The CnGS12/DNA charge ratio was ranging from 0 to 2. A sample containing DNA and EtBr without liposomes was used as a reference. Diluted solution of EtBr was used as a blank. The fluorescence intensity of the samples was measured 60 minutes after the preparation with exciting wavelength $\lambda_{e x}=510 \mathrm{~nm}$ and emission wavelength $\lambda_{\text {em }}=596 \mathrm{~nm}$. The fluorescence of each sample was corrected for the background fluorescence of EtBr in the absence of DNA and then normalized to the EtBr fluorescence of the sample containing DNA without CnGS12/DOPE liposomes.

\section{Fluorescence microscopy}

Phase contrast and fluorescence imaging of transfected cells were performed on a Leica DM IL LED microscope equipped with $5 \mathrm{~W}$ LED power supply and with fluorescence illumination source EL6000 with a mercury metal halide light bulb. The green fluorescence of the green fluorescent protein (GFP) was imaged with the L5 filter for green fluorescence (excitation $480 / 40 \mathrm{~nm}$, emission 527/30 nm) using 40×/0.5 objective.

\section{Cell cultivation}

As a model for testing the ability of lipids to transfect mammalian cells the commercially available HEK 293 cell line established from human embryonic kidney epithelium was used. HEK 293 cells were purchased from DSMZ (Deutsche Sammlung von Mikroorganismen und Zellkulturen $\mathrm{GmbH}$, Braunschweig, Germany) and handled as described previously in Karmazinova et al. (2010). Briefly, the cells were grown in DMEM supplemented with $10 \%$ fetal calf serum and $100 \mathrm{U} / \mathrm{ml}$ penicillin-streptomycin and incubated at $37^{\circ} \mathrm{C}$ in a humidified atmosphere of $5 \% \mathrm{CO}_{2}$.

\section{Assessment of cell viability}

Toxicity of CnGS12 liposomes was compared with the toxicity of commercially available transfection reagent Lipofectamine 2000 (Life Technologies, Carlsbad, California). For the assessment of cell viability cells were seeded on a 24-well plate at a density of 35000 cells per well into $500 \mu \mathrm{l}$ of DMEM with supplements as described above. Cells were allowed 24 hours to set on the bottom of a dish. Transfection reagents at the same concentration that was used for the transfection, i.e., $2.1 \mathrm{nmol} / 100 \mu \mathrm{l}$ of CnGS12/DOPE and $1 \mu \mathrm{l} / 100 \mu \mathrm{l}$ of Lipofectamine 2000 were incubated for 
10 min in Opti-MEM (Gibco Life Technologies Co.). $100 \mu \mathrm{l}$ of transfection reagent mixed with Opti-MEM was gently dropped into individual wells. Viable and nonviable cells were discriminated using Trypan Blue staining. $100 \mu \mathrm{l}$ of Trypan Blue (0.4\% solution; Sigma Aldrich Slovakia) was added into single well. After a brief incubation period, cells were photographed using a Leitz Fluovert upright microscope with a camera. The same procedure was used 24, 48 and 72 hours after the addition of the transfection reagent. Total number of cells and the number of blue-stained (damaged) cells was counted from photographs. Cells cultivated in the presence of Lipofectamine 2000 and/or of Opti-MEM only were used as a control. Photographing and subsequent counting was used to minimize the exposure of cells to Trypan Blue, which itself is toxic to the cells. The experiments were repeated 6 times (CnGS12/DOPE) or 3 times (both controls).

\section{Assessment of transfection efficiency}

To assess transfection efficiency cells were seeded on 35 $\mathrm{mm}$ plastic Petri dishes at a density of 100,000 cells per dish in the culture media described above. The surface of culture dishes was not treated with any polymer. Cells were allowed 24 hours to attach to the bottom of the dish before being transfected with a pEGFP-N1 plasmid DNA (Clontech, Saint-Germain-en-Laye, France) containing gene encoding the Enhanced green fluorescence protein Transfection reagents of the lipid CnGS12 and Lipofectamine 2000 were prepared as described above. pEGFP$\mathrm{N} 1$ plasmid DNA at the concentration $1.6 \mu \mathrm{g} / 100 \mu \mathrm{l}$ was added to Opti-MEM or DMEM. After 10 min incubation, equal volume of Opti-MEM with plasmid was carefully added to Opti-MEM with transfection reagents and the final mixture was incubated for another $20 \mathrm{~min}$. Afterwards, $540 \mu$ of this mixture was gently dropped into each culture dish. As a negative control, cells with the addition of equal volume of Opti-MEM or Opti-MEM with corresponding amount of $\mathrm{pEGFP-N1}$ plasmid DNA without any transfection reagent were used.

To detect cells expressing green fluorescent protein, they were manually harvested by washing the cultivation dishes with phosphate-buffered saline (PBS), centrifuged at 1000 rpm for $10 \mathrm{~min}$, resuspended in $1 \mathrm{ml}$ of cold PBS and put on ice. Damaged cells were marked by propidium iodide (PI). The cells were then analyzed on Accuri C6 flow cytometer. PI-stained cells were excluded from the final analysis. Experiments were repeated 3 times.

\section{Statistical analysis}

Data from transfection and cell viability experiments are presented as mean \pm SD. The significance of the results was statistically analyzed by a one-way analysis of variance (ANOVA) with Tukey's post hoc test. Statistical significance was set at $p<0.05$.

\section{Results}

\section{Small angle X-ray diffraction}

In our work, we studied the structure of CnGS12/DOPE/ DNA ( $n=3,6$ and 12) lipoplexes hydrated by the mixture of DMEM and Opti-MEM media. The structure was evaluated with respect to the spacer length of CnGS12 and the charge ratio CnGS12/DNA. Figure 1A and Figure 1B show SAXD patterns of C3GS12/DOPE/DNA and C12GS12/DOPE/ DNA lipoplexes prepared at CnGS12/DOPE $=0.3 \mathrm{~mol} /$ mol at various CnGS12/DNA charge ratios and hydrated by DMEM/Opti-MEM hydrating medium (at $20^{\circ} \mathrm{C}$ ). Diffraction patterns are typical for a condensed lamellar phase $\left(L_{\alpha}{ }^{c}\right)$ (Lasic 1997; Rädler et al. 1997). Two sharp peaks $L(1)$ and $L(2)$ correspond to a lamellar structure of stacked lipid bilayers, and a small broad peak corresponds to DNA chains packed regularly between the lipid bilayers. From the positions of $L(1)$ and the peak of DNA structural parameters of $L_{\alpha}{ }^{c}$ phase were determined. The repeat distance of condensed lamellar phase $d$ was evaluated as $d=1 / s_{1}$, where $s_{1}$ is the position of first order peak maximum. The repeat distance $d$ involves the thickness of phospholipid bilayer $d_{L}$ and the water layer thickness, $d_{W}$, containing a monolayer of hydrated DNA chains, thus $d=d_{L}+d_{W}$. The DNA repeat distance $d_{D N A}$ is the distance of parallel periodically spaced DNA chains, evaluated as $d_{D N A}=1 / s_{D N A}$ where $s_{D N A}$ is the position of the maximum of the DNA peak. Similar diffractograms were obtained also for C6GS12/DOPE/DNA lipoplexes (see Fig. S1 in Supplementary material).

The effect of CnGS12/DNA charge ratio on structural parameters of lipoplexes prepared at $\mathrm{CnGS12} / \mathrm{DOPE}=$ $0.3 \mathrm{~mol} / \mathrm{mol}$ is plotted in Figure 1C. It is evident that the CnGS12/DNA charge ratio has only minor effect on the repeat distance of $L_{\alpha}{ }^{c}$ phase, however, significant changes in $d_{D N A}$ are observed in all studied CnGS12/DOPE/DNA lipoplexes.

\section{Fluorescence experiments}

Lipoplexes are formed spontaneously due to electrostatic interaction between DNA polyanion and liposomes with positively charged surface. High concentration of salt in water medium modulates this interaction. Studies on the effect of ionic strength on DNA-cationic liposomes complexes have shown that the increase in ionic strength reduces the amount of DNA that cationic liposomes are able to bind (Lobo et al. 2001; Wang et al. 2007; Pullmannová et al. 2012a). 

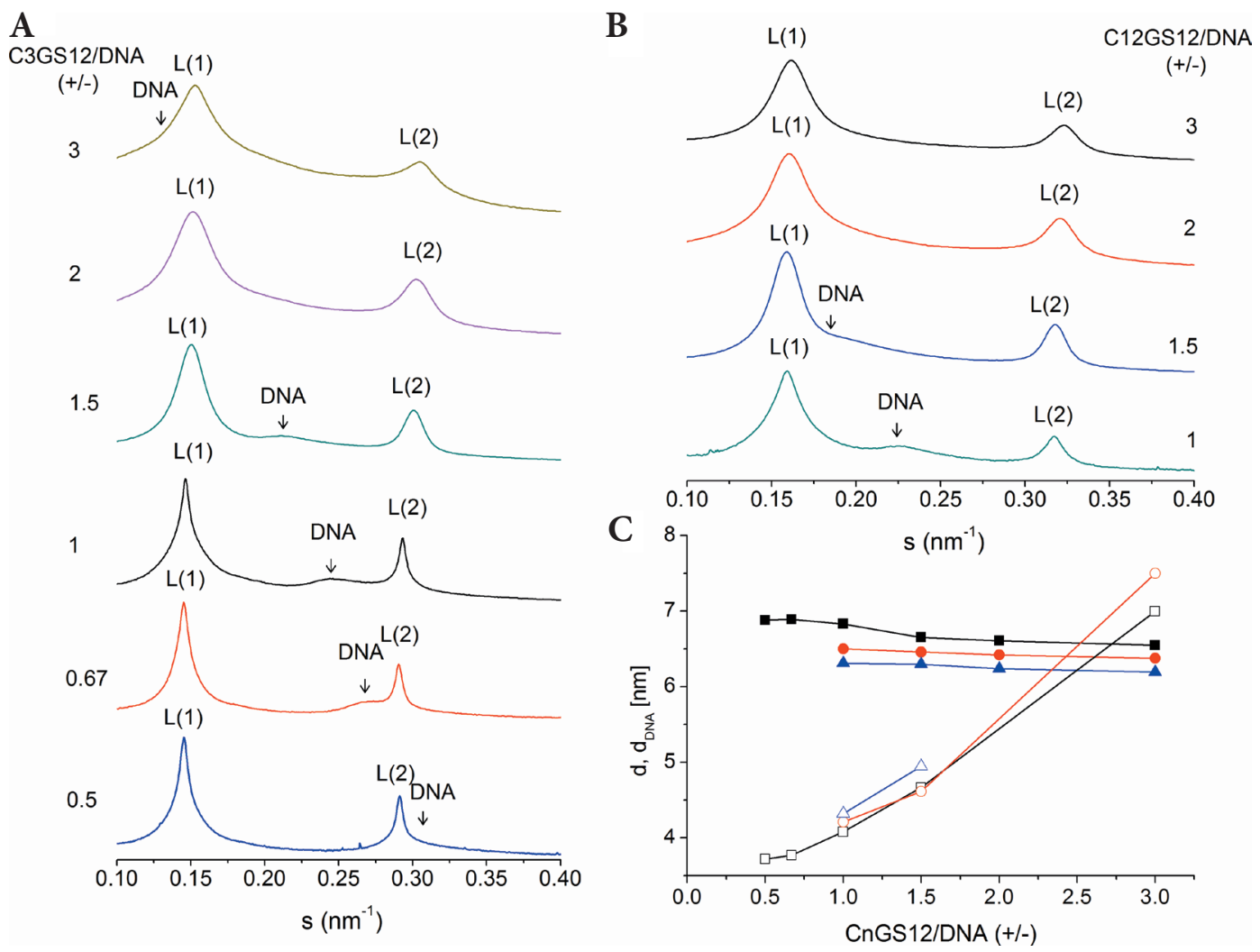

Figure 1. A. SAXD patterns of C3GS12/DOPE/DNA lipoplexes at molar ratio C3GS12/DOPE $=0.3$ and charge ratios C3GS12/DNA $=0.5-3$ in Opti-MEM + DMEM medium. The relative intensity is in logarithmic scale. L(1), L(2), the first and second peak of lamellar phase; $s$, the reciprocal distance. B. SAXD patterns of C12GS12/DOPE/DNA lipoplexes at molar ratio C12GS12/DOPE $=0.3$ and charge ratios $\mathrm{C} 12 \mathrm{GS} 12 / \mathrm{DNA}=1-3$ in Opti-MEM + DMEM medium. The relative intensity is in logarithmic scale. C. Effect of the charge ratio CnGS12/DNA on repeat distance $d$ (full symbols) and DNA repeat distance $d_{D N A}$ (empty symbols) of CnGS12/DOPE/DNA (n $=3(\mathbf{\bullet})$, $6(\bullet)$ and $12(\boldsymbol{\Delta}))$ lipoplexes prepared at molar ratio CnGS12/DOPE = 0.3 in Opti-MEM + DMEM medium.

We performed fluorescence spectroscopy experiments with the aim to evaluate the fraction of DNA condensed between the cationic CnGS12/DOPE bilayers. The process of DNA condensation was followed through changes in emission intensity of fluorescent probe EtBr. Free EtBr in an aqueous solution follows a nonradiative decay pathway that involves donation of an amino group proton to the solvent. When intercalated between base pairs of DNA, the ethidium cation is isolated from the solvent and the proton transfer pathway between EtBr and the solvent is blocked. This leads to about 20-fold increase in emission intensity (Izumrudov et al. 2002). Neutralization of the negative charge of DNA phosphate groups, due to its interaction with CL, leads to the condensation of DNA (Wiethoff et al. 2003) resulting in the displacement of intercalated EtBr manifested as a decrease of fluorescence intensity (Eastman et al. 1997; Izumrudov et al. 2002).

The dependence of normalized fluorescence emission intensity of EtBr on the CnGS12/DNA charge ratio is shown

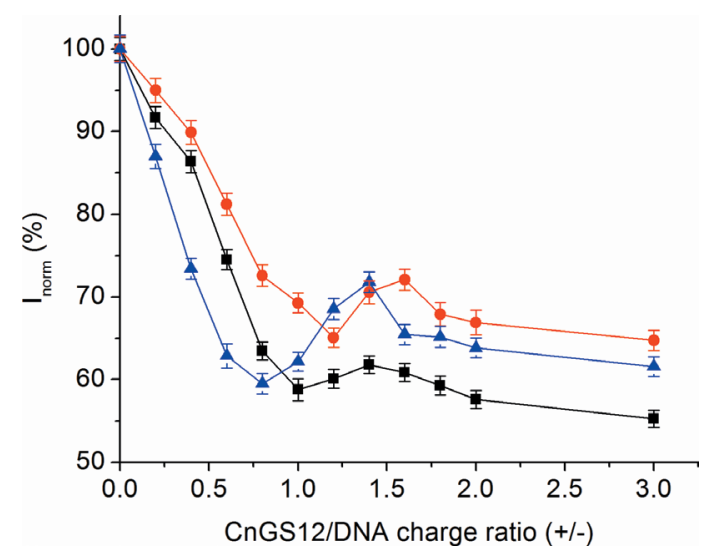

Figure 2. Effect of C3GS12/DOPE (•), C6GS12/DOPE (•) and C12GS12/DOPE ( $\mathbf{\Delta}$ ) cationic liposomes' concentration expressed as $\mathrm{CnGS12/DNA}$ charge ratio on fluorescence intensity of EtBr (DNA/EtBr $=6 \mathrm{~mol} / \mathrm{mol}$ ) in $150 \mathrm{mM} \mathrm{NaCl}$ at $20^{\circ} \mathrm{C}$. The molar ratio of CnGS12/DOPE of liposomes was $0.3 \mathrm{~mol} / \mathrm{mol}$. 


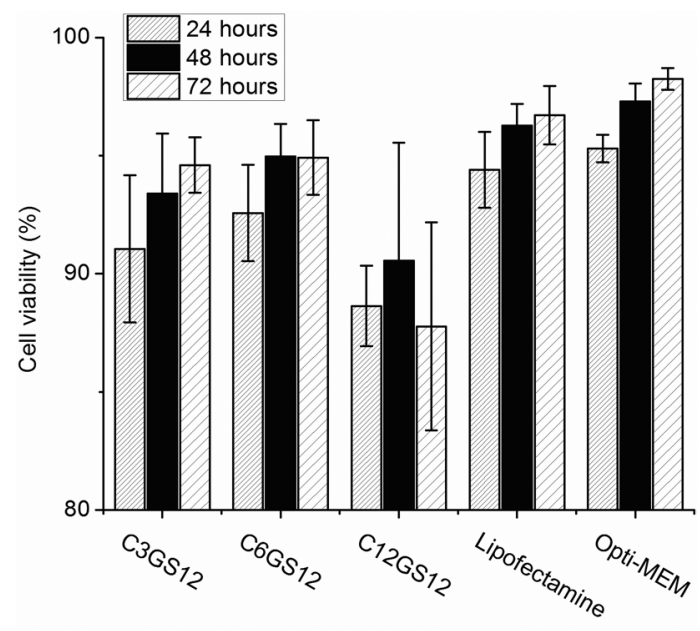

Figure 3. Effect of CnGS12/DOPE ( $n=3,6$ and 12) cationic liposomes $(2.1 \mathrm{nmol} /$ well of CnGS12) and Lipofectamine 2000 ( $1 \mu \mathrm{l} /$ well) on the cell viability of HEK 293 cell line. Percentage of viable cells was evaluated after 24,48 and $72 \mathrm{~h}$ incubation with each lipid as marked in the graph. The molar ratio of CnGS12/ DOPE cationic liposomes was 0.3 . The cells incubated with an addition of Opti-MEM medium only were used as a control. Columns represent means \pm S.D. from 6 independent experiments (CnGS12/DOPE) or 3 independent experiments (both controls). After 72 h cell viability was significantly different (one-way ANOVA with Tukey post hoc test): C3GS12 versus both controls $(p<0.05)$; C6GS12 versus Opti-MEM $(p<0.05)$; C12GS12 versus both controls $(p<0.001)$.

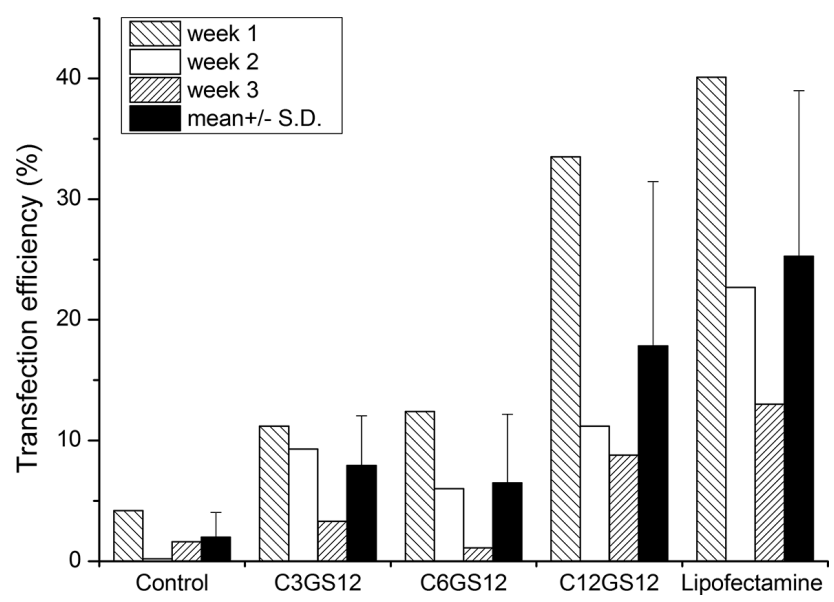

Figure 4. Transfection efficiency (\% of GFP-expressing cells) of pEGFP-N1 plasmid DNA with CnGS12/DOPE liposomes $(n=3$, 6 and 12) in HEK 293 cells $48 \mathrm{~h}$ after transfection. The charge ratio CnGS12/DNA was 1.5 (+/-). The cells transfected with Lipofectamine 2000 were used as a positive control. Cells incubated with pEGFP plasmid DNA without transfection agent were used as a negative control. Columns represent three independent transfections and their mean \pm S.D. in Figure 2. With increasing CnGS12/DNA charge ratio fluorescence intensity of EtBr sharply decreases and reaches the minimum at the CnGS12/DNA charge ratio close to the theoretical isoelectric point. We found the minimum at the charge ratios of C3GS12/DNA $=1, \mathrm{C} 6 \mathrm{GS} 12 / \mathrm{DNA}=1.2$ and $\mathrm{C} 12 \mathrm{GS} 12 / \mathrm{DNA}=0.8(+/-)$ which represents $\sim 60-65 \%$ of the emission maxima of DNA/EtBr in the sample without cationic liposomes. These results suggest that at isoelectric CnGS12/DNA composition there is still over $60 \%$ of DNA accessible for EtBr. This uncondensed DNA consists of free (unbound) DNA in aqueous medium and DNA bound in lipoplexes, but still occurring in the conformation partially accessible to EtBr. According to the values of normalized fluorescence intensity below the isoelectric point the DNA condensation was the most effective with C12GS12/DOPE liposomes followed by C3GS12/DOPE liposomes. C6GS12/ DOPE liposomes were the least effective. These findings correspond well with the binding capacity of C3GS12/ DOPE/DNA lipoplexes prepared in the Opti-MEM/DMEM mixed medium. Quantitative determination of DNA has shown that there is still $\sim 40 \%$ of total DNA volume not bound in lipoplexes that were prepared at their isoelectric point (data are shown in Fig. S2 in Supplementary material).

\section{Cell viability}

Cytotoxicity of CnGS12/DOPE ( $n=3,6$, and 12 ) cationic liposomes for mammalian cells was tested on HEK 293 cell line. CnGS12/DOPE liposomes were applied in concentrations used also for gene transfection and damaged cells were identified with Trypan Blue staining. Cell viability was expressed as percentage of non-stained cells relative to the total number of cells in the analysed visual field. The viability of cells incubated with C3GS12/DOPE and C6GS12/DOPE was comparable with the viability of cells incubated with Lipofectamine 2000 and/or with an addition of Opti-MEM only (Fig. 3). Cells treated with C12GS12/DOPE liposomes showed the lowest viability.

\section{Transfection experiments}

Flow cytometry was used to determine the transfection efficiency of CnGS12/DOPE liposomes in delivery of pEGFP-N1 into HEK 293 cells. Transfection efficiency was expressed as a percentage of GFP-expressing cells relative to all viable cells. 10000 cells from each individual dish were used for the analysis. Figure 4 shows pEGFP plasmid DNA transfection efficiency of all tested CnGS12 and Lipofectamine 2000 as positive control $48 \mathrm{~h}$ after transfection. The transfection efficiency is shown separately for each individual repetition of the experiment and also as their mean value. Background fluorescence measured 
from cells incubated with pEGFP-N1 plasmid DNA without any transfection reagent was around $2 \%$. As seen the value of transfection efficiency varied widely between the individual experiments, however, the order of the transfection efficiency of tested lipoplexes remained roughly unchanged. The best transfection efficiency was reached using C12GS12/DOPE liposomes with the mean value approximately $70 \%$ of the transfection efficiency of Lipofectamine 2000. The CnGS12 with shorter spacers were significantly less efficient achieving only 30\% (C3GS12) and $\sim 25 \%$ (C6GS12) of the transfection efficiency of Lipofectamine 2000. The statistical analysis showed no significant differences $(p<0.05)$ between tested CnGS12 and controls. Figure 5 shows the dependence of pEGFP plasmid DNA transfection efficiency on the concentration of C12GS12/DOPE liposomes in HEK 293 cells evaluated $48 \mathrm{~h}$ after transfection. The transfection efficiency is plotted separately for each individual experiment and also as a mean of all repetitions. The statistical analysis showed no significant differences $(p<0.05)$ between tested concentrations of C12GS12/DOPE liposomes, however, the efficiency was rising with the C12GS12/DOPE concentration in all three repetitions of the experiment. The same experiment was repeated for C3GS12/DOPE liposomes, however, the charge ratio (+/-) was extended up to C3GS12/DNA $=3$. Transfection efficiency determined $48 \mathrm{~h}$ after the treatment as a function of C3GS12/DNA charge ratio is shown in Figure 6. In this case we plotted only the average values of transfection efficiency as in this experiment all 3 repetitions were performed together at the same time. Therefore, the variations caused by different condition of cells were not present in this experiment. The statistical evaluation showed the significant difference between the charge ratio C3GS12/DNA $=3$ and all lower concentrations at $p<0.01$.

\section{Discussion}

\section{Structure of CnGS12/DOPE/DNA lipoplexes}

Structural design of a nucleic acid carrier is considered to be a crucial step in ensuring the success of gene delivery. SAXD experiments have confirmed the presence of a condensed lamellar phase $L_{\alpha}{ }^{c}$ in all studied complexes. The repeat distance $d$ shows a small decrease with increasing CnGS12/ DNA charge ratio (Fig. 1C) that we attribute to lower content of DNA in lipoplexes, what changes the water layer thickness of the $L_{\alpha}{ }^{c}$ phase. The effect of the CnGS12/DNA charge ratio is more significantly manifested on the DNA repeat distance of lipoplexes. DNA chains drift away from each other with increasing (+/-) charge ratio, what displays as the increase of $d_{D N A}$ from $3.72 \mathrm{~nm}$ at the charge ratio C3GS12/DNA $=0.5$ to $6.99 \mathrm{~nm}$ at the charge ratio $\mathrm{C} 3 \mathrm{GS} 12 / \mathrm{DNA}=3$ and from 4.21

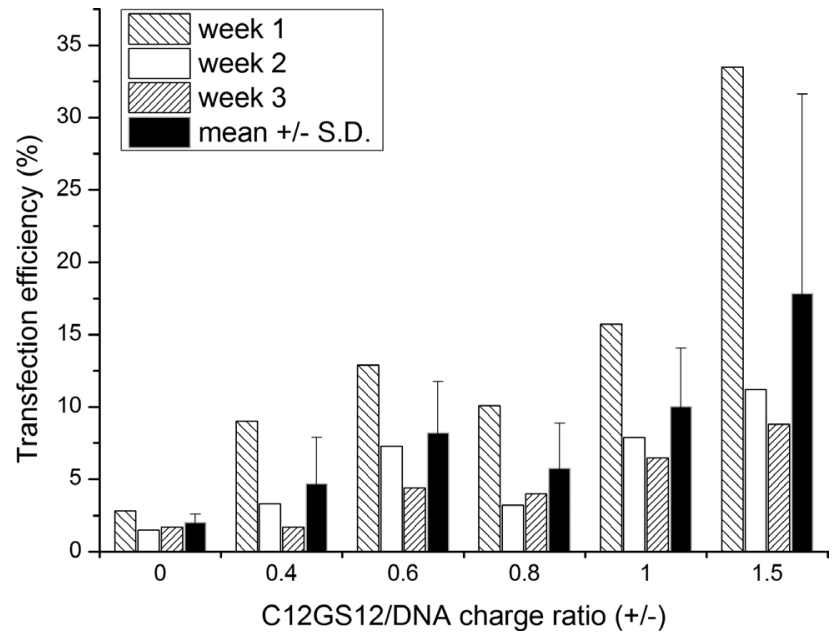

Figure 5. Dependence of pEGFP plasmid DNA transfection efficiency on the concentration of C12GS12/DOPE liposomes in HEK 293 cells $48 \mathrm{~h}$ after transfection. The DNA concentration was $4.3 \mu \mathrm{g} /$ dish. Cells incubated with pEGFP plasmid DNA without transfection reagent were used as a negative control. Columns represent three independent transfections and their mean \pm S.D. The mean value at the charge ratio C12GS12/DNA $=1.5$ was significantly different (one-way ANOVA with Tukey post hoc test): versus all lower charge ratios at $p<0.05$.

at the charge ratio C6GS12/DNA $=1$ up to $7.50 \mathrm{~nm}$ at the charge ratio C6GS12/DNA $=3$. For C12GS12/DOPE/DNA lipoplexes we identified peak of DNA only at (+/-) charge ratios 1 and 1.5 with observed increase of $d_{D N A}$ from 4.32 to $4.95 \mathrm{~nm}$. At higher charge ratios the peak of DNA was

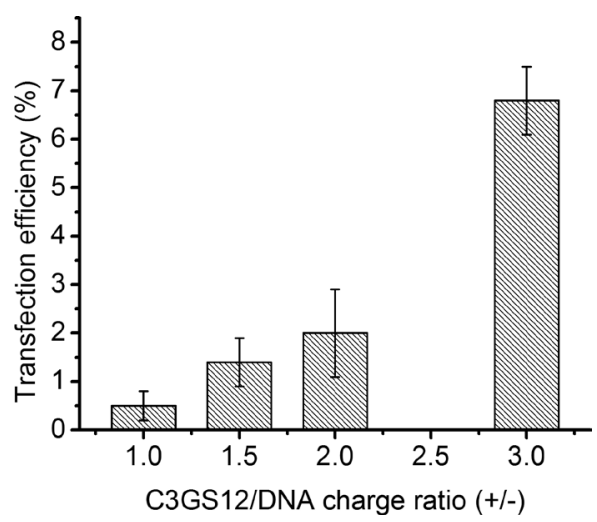

Figure 6. Dependence of pEGFP plasmid DNA transfection efficiency on the concentration of C3GS12/DOPE liposomes in HEK 293 cells $48 \mathrm{~h}$ after transfection. Cells incubated with pEGFP plasmid DNA without transfection reagent were used as a negative control. Columns represent mean \pm S.D. from three independent transfections. The mean value at the charge ratio C3GS12/DNA $=3$ was significantly different (one-way ANOVA with Tukey post hoc test): versus all lower charge ratios at $p<0.01$. 
overlapped by the first peak of the $L_{\alpha}{ }^{c}$ phase. This observed increase of $d_{D N A}$ corresponds with findings of Koltover et al. (1999) in the system cationic lipid-neutral lipid-DNA. The excess of DNA can be driven into the isoelectric complex by an osmotic pressure of its confined counterions leading to the reduction of $d_{D N A}$ and negative overcharging. However, the DNA intake is limited due to the increase of counterion concentration inside the complex and because of the electrostatic repulsion of additional DNA molecules, whose anionic charge is not compensated by the cationic charge of the bound lipids. The system remains a one-phase complex only close to the isoelectric point, and separates into complex + excess of CL or complex + excess of DNA (Koltover et al. 1999). Diffractograms of our lipoplexes show the presence of only one $L_{\alpha}{ }^{c}$ phase. Both the fraction of the CnGS12 surfactant (i.e. CnGS12/DOPE molar ratio) and the length $(n)$ of the CnGS12's spacer modulate the lipoplexes structure in our system. The effect of the CnGS12/DOPE/ DNA composition, the length of the spacer and the effect of the temperature on structural polymorphic behaviour of the mixture was studied in our previous works (Pullmannová et al. 2008, 2012b). In those works, the complexes were prepared at their isoelectric point in $150 \mathrm{mM} \mathrm{NaCl}$. However, for transfection of mammalian cells lipoplexes must be prepared in a suitable cell culture medium. Therefore, it was important to examine possible structural changes caused by the change of hydrating medium (DMEM/Opti-MEM $=1.5 \mathrm{vol} / \mathrm{vol}$ ) used in the current work, that emulated the composition of medium in transfection experiments. Comparing the structural parameters of complexes hydrated by the mixture of Opti-MEM and DMEM to those hydrated by $\mathrm{NaCl}$ with similar ionic strength obtained in Pullmannova et al. (Pullmannová et al. 2012b) minimal changes in the structure were found. It is evident that the composition of the medium did not affect either the structure itself, or structural parameters in a significant way.

\section{DNA condensation}

Both experimental methods confirmed that aqueous medium of ionic strength relevant to the physiological conditions substantially screens DNA-CnGS12/DOPE interaction and the binding capacity of CnGS12/DOPE $=0.3 \mathrm{~mol} / \mathrm{mol}$ liposomes determined at their isoelectric point represented $\sim 40-60 \%$ of DNA in the solution. It is worth to mention that the surface charge density of cationic liposomes (i.e. cationic surfactant/helper lipid molar ratio) affects the volume fraction of DNA bound in lipoplexes. Our research in this field and many performed experiments confirmed that the time plays an important role in this process. Experiments under this study were performed in a time scale determined by experimental protocol for transfection. However, we found up to $83 \pm 7 \%$ of total volume of DNA bound by C3GS12/
$\mathrm{DOPE}=0.3 \mathrm{~mol} / \mathrm{mol}$ liposomes in Opti-MEM and DMEM medium when the sample was stored at $\sim 5^{\circ} \mathrm{C}$ for 1 week (see Fig. S3 in Supplementary material).

Fluorescence experiment documented in Figure 2 indicates "untypical" nature of DNA condensation: We observed a small increase in EtBr emission intensity at the charge ratio CnGS12/DNA > 1, showing a local maximum at CnGS12/ DNA 1.5. This small increase of fluorescence intensity suggests that either the time interval of $60 \mathrm{~min}$ after the preparation was not sufficient to reach a stable system; and/ or the excess of CL in lipoplexes leads to DNA conformational changes that permitted greater accessibility of DNA to intercalate EtBr. The increase of florescence intensity seems to be dependent on the length of CnGS12 spacer, as the fluorescence maximum was higher for lipoplexes with a longer spacer of CnGS12. At (+/-) charge ratios above the isoelectric point, the C3GS12/DOPE liposomes were the most effective in DNA condensation process.

\section{Cells viability and transfection efficiency}

Interestingly, except for cells incubated with C12GS12/ DOPE liposomes, the cell viability of all samples slightly increased with extended time of incubation (Fig. 3). We suggest that the cell division rate was higher than the cell death rate. Gemini surfactants have been found as agents with antimicrobial activity (Devínsky et al. 1985). Imam et al. (1983) reported antimicrobial activity expressed as minimum inhibition concentration (MIC) of CnGS10 against St. aureus, E. coli, and C. Albicans. MIC shows a nonlinear trend with respect to the spacer length. With increasing spacer length the antimicrobial activity first gradually decreased, achieving a minimum at $n \sim 4-5$ carbons and then increased with increasing " $n$ ". Our results are in line with these findings. Recently reported tests of viability of NCTC2544 cell line (a human skin keratinocyte cell line) revealed no significant cytotoxicity up to $10 \mathrm{mM}$ concentration of CnGS12, $n=2$, 6, and 10 (Almeida et al. 2011). At higher concentrations toxicity increased with increasing spacer length and surfactants with longer tail were found to be less toxic than shorter ones. Generally, the toxicity is related to the ability of GS to penetrate into the cell membrane and to disturb its integrity. It is worth to mention the correlation between transfection efficiency of CnGS12/DOPE liposomes and their detected cytotoxicity. Almeida et al. (2011) have shown experimentally that CnGS12 cytotoxicity is caused mainly by the disruption of the cell membrane. The correlation between the observed cytotoxicity and transfection efficiency offers an explanation that the minor disturbance of the cell membrane induced by lipoplexes also facilitates the transfection. We evaluated transfection efficiency of CnGS12/DOPE liposomes as a percentage of GFP-expressing cells relative to all viable cells using HEK 293 cell line as a model. The best 
transfection efficiency was detected for lipoplexes prepared from C12GS12/DOPE liposomes (Fig. 4 and 5). The obtained efficiency of CnGS12/DOPE ( $n=3,6$ and 12) liposomes correlates with their efficiency in DNA compaction and is in proportional relation to the toxicity of the cationic agent. Although the statistical analysis showed no significant differences $(p<0.05)$ between any of the tested CnGS12 or both controls, we believe that this was caused by the differences in the condition of transfected cells and changes in other factors between the individual repetitions of the experiment. The observed changes in transfection efficiency between the experiments were relatively large; however the order of the efficiency of tested vectors remained roughly unchanged. Badea et al. (2005) reported an inverse relation between the spacer length and transfection efficiency. In their work lipoplexes with short spacer of GS were the most efficient. These authors tested transfection efficiency using a different cellular model (PAM 201 keratinocyte culture), different method for lipoplex preparation and also lipoplexes with higher content of CnGS12 (higher surface charge density) were used (Badea et al. 2005; Fisicaro et al. 2005). Therefore our results cannot be directly compared. Muñoz-Úbeda et al. (2012) tested transfection efficiency of CnGS16s with 16 carbon alkyl chains in mixtures with DOPE. Depending on the variation of CnGS16/DOPE molar ratios they found a different order of transfection efficiency based on CnGS16 spacer length. At low content of CnGS16 close to our CnGS12/DOPE molar ratio $(0.3 \mathrm{~mol} / \mathrm{mol}) \mathrm{GS}$ with a longer spacer was found to be the most efficient. In contrast to that, at the molar ratio CnGS16/DOPE $\geq 1$ the efficiency of CnGS16 with shorter spacers $(n=2,3)$ has significantly risen up and has overcome the efficiency of derivatives with longer spacers.
We examined the transfection efficiency of our lipoplexes regarding the charge ratio of CnGS12/DNA for CnGS12, $n=3$ and 12 , considering this system to be the most efficient transfection agents as it was found in our work and in Badea et al. (2005). The increase of the C3GS12/DNA charge ratio from 1-3 (+/-) caused the increase of transfection efficiency 14-fold, but did not even reach the level of the efficiency of C12GS12/DNA at lower charge ratios (Fig. 5 and Fig. 6). Fluorescence microscopy images in Figure 7 illustrate this increase by means of higher number of pEGFP positive cells. Transfected cells exhibit green signal on the micrographs. Elongation of the spacer length and the increase of the CnGS12/DNA charge ratio increases the cytotoxicity as indicated in our cell viability experiments. Therefore the C12GS12/DNA charge ratio was studied in the range $0.4 \leq \mathrm{C} 12 \mathrm{GS} 12 / \mathrm{DNA} \leq 1.5$ (Fig. 6). The transfection efficiency increased with increasing C12GS12/DNA charge ratio as in the case of C3GS12/DNA. DMEM used for C3GS12/DNA liposomes was replaced by Opti-MEM after improved transfection efficiency with Opti-MEM was revealed. The influence of medium used for the transfection was studied before by Young at al. (2004) with similar results. This effect can be seen in Figure 4 and Figure 6 at the charge ratio $\mathrm{C} 3 \mathrm{GS} 12 / \mathrm{DNA}=1.5(+/-)$.

DNA dose was kept constant in our transfection experimental protocol and the (+/-) charge ratio was modulated through the volume fraction of CnGS12/DOPE liposomes. Experimental results demonstrate a key role of ionic strength of aqueous medium in the volume of DNA fraction bound in lipoplexes. The slope of dependences $I_{\text {norm }} v s .(+/-)$ charge ratio (Fig. 2) shows C12GS12 to be the most efficient agent for DNA packing at the charge ratios $(+/-) \leq 1$. In complexes with GS the length of the spacer and its flexibility modulate
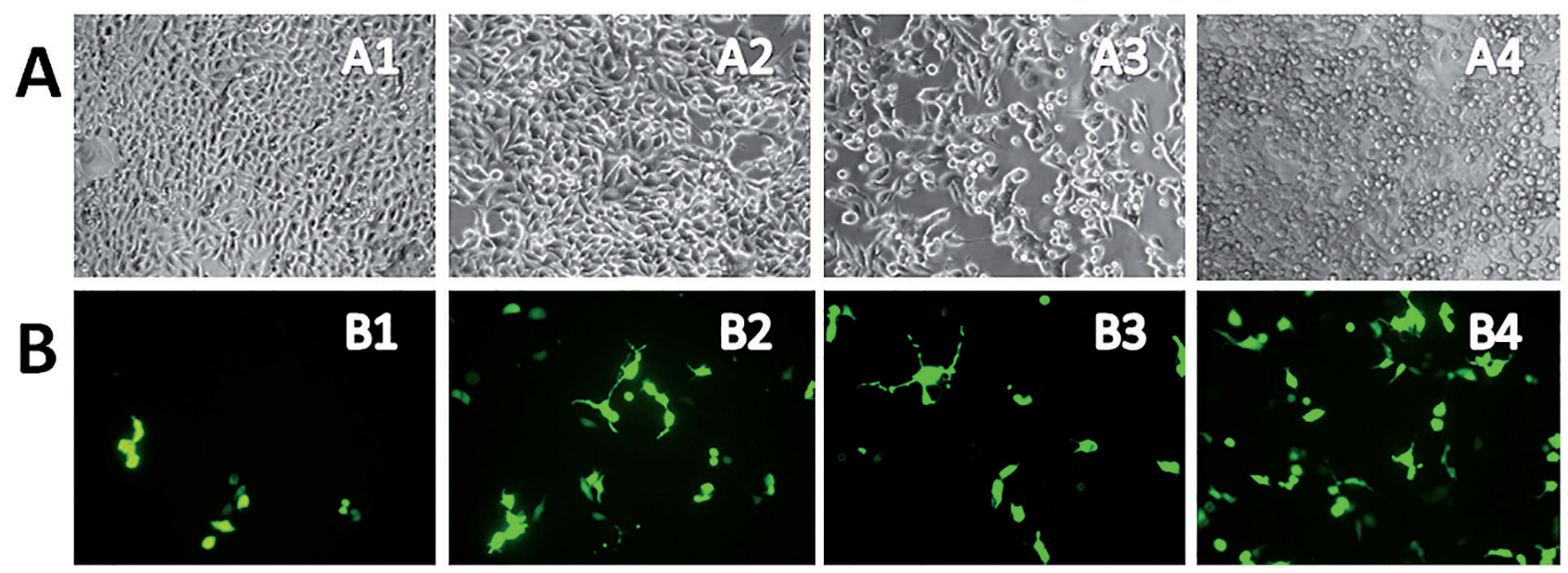

Figure 7. Micrographs of mammalian HEK 293 cells transfected with pEGFP-C1 taken $48 \mathrm{~h}$ after transfection. A. Phase contrast micrographs. B. Fluorescence micrographs with GFP expression at the same visual field. Charge ratios C3GS12/DNA were as follows: A1, B1 $=1(+/-), \mathrm{A} 2, \mathrm{~B} 2=1.5(+/-), \mathrm{A} 3, \mathrm{~B} 3=2(+/-)$ and $\mathrm{A} 4, \mathrm{~B} 4=3(+/-)$. 
the freedom of $R_{4} N^{+}$group arrangements in the vicinity of DNA. The distance between cationic moieties of a short spacer $(n=2,3)$ is fixed. Molecular dynamic simulation of the dipalmitoylphosphatidylcholine (DPPC) bilayer with inserted CnGS12 molecules have determined $R_{4} N^{+}$groups separated by $0.5 \pm 0.1 \mathrm{~nm}$ in C2GS12 molecule (Almeida et al. 2011). GS with a short spacer $(n=2,3)$ were found to be the most efficient in DNA-GS compaction. The spacing between positive charges localized in the hydrophilic headgroups of GS is so small that the surfactant acts like a divalent cationic surfactant (Karlsson et al. 2002). On the other hand, longer spacers $(n=10-12)$ are flexible and hydrophobic enough to fold into the membrane's hydrophobic region (Alami et al. 1993; Pisárčik et al. 2005). Molecular dynamic simulation for the model DPPC/C10GS12 predicts $R_{4} N^{+}$ groups separated by $1.4 \pm 0.2 \mathrm{~nm}$ (Almeida et al. 2011). In such a system, positive $R_{4} N^{+}$groups of GS localized in the polar headgroup of the DOPE membrane create surface charge density more or less similar to univalent cationic surfactants (of twice concentration in respect to the charge) with "a movement freedom" dictated by the flexibility of a long spacer. In spite of the charge screening due to high ionic strength of the aqueous medium, one can see that at the same molar fraction $(\mathrm{CnGS} 12 / \mathrm{DOPE}=0.3 \mathrm{~mol} / \mathrm{mol})$ GnGS12 with a long spacer $(n=12)$ and those with the short one $(n=3)$ enable more efficient condensation of DNA in comparison to CnGS12 of intermediate spacer $(n=6)$ (see Fig. 2).

We can conclude that the observed transfection efficiency of CnGS12/DOPE ( $n=3,6$ and 12) lipoplexes forming condensed lamellar phase $\left(L_{\alpha}{ }^{c}\right)$ correlates with their efficiency in DNA compaction and proportionally with the toxicity of the cationic agent.

\section{Conclusions}

The aim of our work was to evaluate the in vitro transfection efficiency and cytotoxicity of selected CnGS12/DOPE liposomes, focusing on the biophysical characteristicstransfection activity relationship. The structure of lipoplexes and their binding capacity for DNA was examined under conditions of a standard transfection protocol. Lipoplexes were prepared as a mixture of neutral helper lipid, DOPE, and cationic gemini surfactants CnGS12 with three different spacer lengths: $n=3,6$ and 12 . The surface charge density of liposomes was modulated by the CnGS12/DOPE molar ratio to keep the microstructure in the lamellar phase. Small angle $\mathrm{X}$-ray diffraction experiments have confirmed the presence of a condensed lamellar phase $L_{\alpha}{ }^{c}$ with the repeat distance $d \sim 6-7 \mathrm{~nm}$ and DNA chains regularly packed showing strong dependence of $d_{D N A}$ on the CnGS12/DNA charge ratio. $\mathrm{DMEM} / \mathrm{Opti}-\mathrm{MEM}=1.5 \mathrm{vol} / \mathrm{vol}$ (aqueous medium used in transfection experiments) used as hydrating medium showed no significant effect on structural parameters of formed lipoplexes comparing to our previous experiments with lipoplexes hydrated with $150 \mathrm{mM} \mathrm{NaCl}$ (Pullmannová et al. 2012b). However, we found that high ionic strength of hydrating medium reduced substantially the volume fraction of DNA bound within the lipoplexes. Maximally 60\% of total volume of DNA related to the theoretical isoelectric point was bound in lipoplexes and its dependence on the CnGS12 spacer length was insignificant $( \pm 10 \%)$. The amount of condensed DNA showed dependence on both spacer length and (+/-) charge ratio and reached maximally $45 \%$ of DNA present in the sample. Transfection efficiency of CnGS12/DOPE liposomes was evaluated as a percentage of GFP-expressing cells relative to all viable cells using HEK 293 cell line as a model. The observed transfection efficiency of CnGS12/DOPE ( $n=3,6$ and 12) lipoplexes correlated with their efficiency for DNA compaction and was in proportional relation to the toxicity of the cationic agent. The best transfection efficiency was detected for lipoplexes prepared from C12GS12/DOPE liposomes. The results presented here provide useful information for successful design of novel lipoplexes.

Acknowledgement. The authors thank the staff of SAXS beamline (Elettra synchrotron, Trieste) for their assistance and help with the experiments. The research leading to these results has received funding from the European Community's Seventh Framework Programme (FP7/2007-2013) under grant agreement $\mathrm{n}^{\circ} 312284$ " (proposal 20135192) and $n^{\circ} 226716$ (HASYLAB project II-20100372 EC), by the JINR project 04-4-1121-2015/2017 and grants APVV- 0212-10; APVV 0516-12, VEGA 1/0916/16, FaF UK/44/2016 and UK/254/2017. DG thanks Slovak Academic Information Agency (SAIA) for funding her during her work at IMB in Mainz. Support by IMB's Flow Cytometry Core Facility and the use of its LSR Fortessa (INST 247/646-1 FUGG) is gratefully acknowledged.

\section{References}

Alami E, Beinert G, Marie P, Zana R (1993): Alkanediyl-alpha, omega-bis(dimethylalkylammonium bromide) surfactants. 3. Behavior at the air-water interface. Langmuir 9, 1465-1467 https://doi.org/10.1021/la00030a006

Almeida JAS, Faneca H, Carvalho RA, Marques EF, Pais AACC (2011): dicationic alkylammonium bromide gemini surfactants. Membrane perturbation and skin irritation. PLoS ONE 6, e26965 https://doi.org/10.1371/journal.pone.0026965

Badea I, Verrall R, Baca-Estrada M, Tikoo S, Rosenberg A, Kumar P, Foldvari M (2005): In vivo cutaneous interferon- $\gamma$ gene delivery using novel dicationic (gemini) surfactant-plasmid complexes. J. Gene Med. 7, 1200-1214 https://doi.org/10.1002/jgm.763 
Barreleiro PCA, Olofsson G, Alexandridis P (2000): Interaction of DNA with cationic vesicles: A calorimetric study. J. Phys. Chem. B 104, 7795-7802 https://doi.org/10.1021/jp000636c

Belicová A, Ebringer L, Devínsky F (1995): Plasmid curing capacity of bisquaternary ammonium-salts - comparison of 4 sets of N,N'-bis(alkydimethyl)-3-X-1,5- pentanediammonium dibromides. Biol. Zentralblatt 114, 294-298

Bell PC, Bergsma M, Dolbnya IP, Bras W, Stuart MCA, Rowan AE, Feiters MC, Engberts JBFN (2003): Transfection mediated by gemini surfactants: engineered escape from the endosomal compartment. J. Am. Chem. Soc. 125, 1551-1558 https://doi.org/10.1021/ja020707g

Bombelli C, Faggioli F, Luciani P, Mancini G, Sacco MG (2005) Efficient transfection of DNA by liposomes formulated with cationic gemini amphiphiles. J. Med. Chem. 48, 5378-5382 https://doi.org/10.1021/jm050477r

Camilleri P, Kremer A, Edwards AJ, Jennings KH, Jenkins O, Marshall I, McGregor C, Neville W, Rice SQ, Smith RJ, Wilkinson MJ, Kirby AJ (2000): A novel class of cationic gemini surfactants showing efficient in vitro gene transfection properties. Chem. Commun. 1253-1254 https://doi.org/10.1039/b001742f

Caracciolo G, Pozzi D, Caminiti R, Marchini C, Montani M, Amici A, Amenitsch H (2007): Transfection efficiency boost by designer multicomponent lipoplexes. Biochim. Biophys. Acta $\mathbf{1 7 6 8 , 2 2 8 0 - 2 2 9 2}$ https://doi.org/10.1016/j.bbamem.2007.06.027

Cardoso AM, Morais CM, Cruz AR, Silva SG, do Vale ML, Marques EF, de Lima MCP, Jurado AS (2015): New serine-derived gemini surfactants as gene delivery systems. Eur. J. Pharm. Biopharm. 89, 347-356 https://doi.org/10.1016/j.ejpb.2014.12.013

Cardoso AMS, Faneca H, Almeida JAS, Pais AACC, Marques EF, de Lima MCP, Jurado AS. (2011): Gemini surfactant dimethylene-1,2-bis(tetradecyldimethylammonium bromide)-based gene vectors: a biophysical approach to transfection efficiency. Biochim. Biophys. Acta 1808, 341-351 https://doi.org/10.1016/j.bbamem.2010.09.026

Devínsky F, Lacko I, Bitterová F, Mlynarčík D (1987): Quaternary ammonium-salts. 18. Preparation and relationship between structure, IR spectral characteristics, and antimicrobial activity of some new bis-quaternary isosters of 1,5-pentanediammonium dibromides. Chem. Pap. 41, 803-814

Devínsky F, Lacko I, Mlynarčík D, Račanský V, Krasnec L' (1985): Relationship between critical micelle concentrations and minimum inhibitory concentrations for some non-aromatic quaternary ammonium salts and amine oxides. Tenside Deterg. 22, 10-15

Djurovic S, Iversen N, Jeansson S, Hoover F, Christensen G (2004): Comparison of nonviral transfection and adeno-associated viral transduction on cardiomyocytes. Mol. Biotechnol. 28, $21-32$ https://doi.org/10.1385/MB:28:1:21

Donkuru M, Badea I, Wettig S, Verrall R, Elsabahy M, Foldvari M (2010): Advancing nonviral gene delivery: lipid- and surfactantbased nanoparticle design strategies. Nanomed. 5, 1103-1127 https://doi.org/10.2217/nnm.10.80
Donkuru M, Wettig SD, Verrall RE, Badea I, Foldvari M (2012): Designing $\mathrm{pH}$-sensitive gemini nanoparticles for non-viral gene delivery into keratinocytes. J. Mater. Chem. 22, 6232-6244 https://doi.org/10.1039/c2jm15719e

Eastman S, Siegel C, Tousignant J, Smith A, Cheng S, Scheule R (1997): Biophysical characterization of cationic lipid:DNA complexes. Biochim. Biophys. Acta 1325, 41-62 https://doi.org/10.1016/S0005-2736(96)00242-8

Felgner PL, Gadek TR, Holm M, Roman R, Chan HW, Wenz M, Northrop JP, Ringold GM, Danielsen M (1987): Lipofection: a highly efficient, lipid-mediated DNA-transfection procedure. Proc. Natl. Acad. Sci. USA 84, 7413-7417 https://doi.org/10.1073/pnas.84.21.7413

Fisicaro E, Compari C, Duce E, Donofrio G, Rózycka-Roszak B, Woźniak E (2005): Biologically active bisquaternary ammonium chlorides: physico-chemical properties of long chain amphiphiles and their evaluation as non-viral vectors for gene delivery. Biochim. Biophys. Acta 1722, 224-233 https://doi.org/10.1016/j.bbagen.2004.12.013

Foldvari M, Badea I, Wettig S, Verrall R, Bagonluri M (2006): Structural characterization of novel gemini non-viral DNA delivery systems for cutaneous gene therapy. J. Exp. Nanosci. 1, 165-176 https://doi.org/10.1080/17458080500411965

Gershon H, Ghirlando R, Guttman SB, Minsky A (1993): Mode of formation and structural features of DNA-cationic liposome complexes used for transfection. Biochemistry (Mosc.) 32, 7143-7151

https://doi.org/10.1021/bi00079a011

Hirata H, Hattori N, Ishida M, Okabayashi H, Frusaka M, Zana R (1995): Small-angle neutron-scattering study of bis(quaternary ammonium bromide) surfactant micelles in water. Effect of the spacer chain length on micellar structure. J. Phys. Chem. 99, 17778-17784 https://doi.org/10.1021/j100050a017

Horniak L, Devínsky F, Balgavý P, Lacko I, Ebringer L (1989): Quaternary ammonium halides for increased efficiency of bacterial transformation. Patent $88 / 3$

Huang TC, Toraya H, Blanton TN, Wu Y (1993): X-ray powder diffraction analysis of silver behenate, a possible low-angle diffraction standard. J. Appl. Crystallogr. 26, 180-184 https://doi.org/10.1107/S0021889892009762

Hung CF, Hwang TL, Chang CC, Fang JY (2005): Physicochemical characterization and gene transfection efficiency of lipid emulsions with various co-emulsifiers. Int. J. Pharm. 289, 197-208 https://doi.org/10.1016/j.ijpharm.2004.11.008

Imam T, Devínsky F, Lacko I, Mlynarčík D, Krasnec L (1983): Preparation and antimicrobial activity of some new bisquaternary ammonium salts. Pharm. 38, 308-310

Izumrudov VA, Zhiryakova MV, Goulko AA (2002): Ethidium bromide as a promising probe for studying DNA interaction with cationic amphiphiles and stability of the resulting complexes. Langmuir 18, 10348-10356 https://doi.org/10.1021/la020592u

Karlsson L, van Eijk MCP, Söderman O (2002): Compaction of DNA by gemini surfactants: effects of surfactant architecture. J. Colloid Interface Sci. 252, 290-296 https://doi.org/10.1006/jcis.2002.8477 
Karmazinova M, Beyl S, Stary-Weinzinger A, Suwattanasophon C, Klugbauer N, Hering S, Lacinova L (2010): Cysteines in the loop between IS5 and the pore helix of $\mathrm{Ca}(\mathrm{V}) 3.1$ are essential for channel gating. Pflüg. Arch. Eur. J. Physiol. 460, 1015-1028 https://doi.org/10.1007/s00424-010-0874-5

Khan M, Ang CY, Wiradharma N, Yong LK, Liu S, Liu L, Gao S, Yang YY (2012): Diaminododecane-based cationic bolaamphiphile as a non-viral gene delivery carrier. Biomaterials 33, 4673-4680 https://doi.org/10.1016/j.biomaterials.2012.02.067

Kirby AJ, Camilleri P, Engberts JBFN, Feiters MC, Nolte RJM, Söderman O, Bergsma M, Bell PC, Fielden ML, García Rodríguez CL, et al. (2003): Gemini surfactants: new synthetic vectors for gene transfection. Angew. Chem. Int. Ed. 42, 1448-1457 https://doi.org/10.1002/anie.200201597

Koltover I, Salditt T, Safinya CR (1999): Phase diagram, stability, and overcharging of lamellar cationic lipid-DNA self-assembled complexes. Biophys. J. 77, 915-924

https://doi.org/10.1016/S0006-3495(99)76942-0

Kumar M, Jinturkar K, Yadav MR, Misra A (2010): Gemini amphiphiles: a novel class of nonviral gene delivery vectors. Crit. Rev. Ther. Drug Carrier Syst. 27, 237-278 https://doi.org/10.1615/CritRevTherDrugCarrierSyst.v27.i3.20

Lasic DD (1997): Colloid chemistry. Liposomes within liposomes. Nature 387, 26-27 https://doi.org/10.1038/387026a0

Lengyel A, Uhríková D, Klacsová M, Balgavý P (2011): DNA condensation and its thermal stability influenced by phospholipid bilayer and divalent cations. Colloids Surf. B Biointerfaces 86, 212-217 https://doi.org/10.1016/j.colsurfb.2011.04.001

Li SD, Huang L (2006): Gene therapy progress and prospects: non-viral gene therapy by systemic delivery. Gene Ther. 13, 1313-1319 https://doi.org/10.1038/sj.gt.3302838

Lobo BA, Davis A, Koe G, Smith JG, Middaugh CR (2001): Isothermal titration calorimetric analysis of the interaction between cationic lipids and plasmid DNA. Arch. Biochem. Biophys. 386, 95-105 https://doi.org/10.1006/abbi.2000.2196

Mu-oz-Úbeda M, Misra SK, Barrán-Berdón AL, Datta S, AicartRamos C, Castro-Hartmann P, Kondaiah P, Junquera E, Bhattacharya S, Aicart E (2012): How does the spacer length of cationic gemini lipids influence the lipoplex formation with plasmid DNA? Physicochemical and biochemical characterizations and their relevance in gene therapy. Biomacromolecules 13, 3926-3937 https://doi.org/10.1021/bm301066w

Perrone S, Usai M, Lazzari P, Tucker SJ, Wallace HM, Zanda M (2013): Efficient cell transfection with melamine-based gemini surfactants. Bioconjug. Chem. 24, 176-187 https://doi.org/10.1021/bc3004292

Pietralik Z, Kołodziejska Ż, Weiss M, Kozak M (2015): Gemini surfactants based on bis-imidazolium alkoxy derivatives as effective agents for delivery of nucleic acids: a structural and spectroscopic study. PloS One 10, e0144373 https://doi.org/10.1371/journal.pone.0144373
Pisárčik M, Rosen MJ, Polakovičová M, Devínsky F, Lacko I (2005): Area per surfactant molecule values of gemini surfactants at the liquid-hydrophobic solid interface. J. Colloid Interface Sci. 289, 560-565 https://doi.org/10.1016/j.jcis.2005.03.092

Pullmannová P, Uhríková D, Funari SS, Lacko I, Devínsky F, Balgavý P (2008): Polymorphic phase behavior of DNA - DOPE - GEMINI surfactant aggregates: a small angle x-ray diffraction. Acta Fac. Pharm. Univ. Comen. 55, 170-182

Pullmannová P, Bastos M, Bai G, Funari SS, Lacko I, Devínsky F, Teixeira J, Uhríková D (2012a): The ionic strength effect on the DNA complexation by DOPC - gemini surfactants liposomes. Biophys. Chem. 160, 35-45 https://doi.org/10.1016/j.bpc.2011.09.002

Pullmannová P, Funari SS, Devínsky F, Uhríková D (2012b): The DNA-DNA spacing in gemini surfactants-DOPE-DNA complexes. Biochim. Biophys. Acta 1818, 2725-2731 https://doi.org/10.1016/j.bbamem.2012.05.021

Rädler JO, Koltover I, Salditt T, Safinya CR (1997): Structure of DNA-cationic liposome complexes: DNA intercalation in multilamellar membranes in distinct interhelical packing regimes. Science 275, 810-814 https://doi.org/10.1126/science.275.5301.810

Rao NM, Gopal V (2006): Cell biological and biophysical aspects of lipid-mediated gene delivery. Biosci. Rep. 26, 301-324 https://doi.org/10.1007/s10540-006-9026-8

Robbins PD, Ghivizzani SC (1998): Viral vectors for gene therapy. Pharmacol. Ther. 80, 35-47 https://doi.org/10.1016/S0163-7258(98)00020-5

Rolland AP (1998): From genes to gene medicines: recent advances in nonviral gene delivery. Crit. Rev. Ther. Drug Carrier Syst. 15, 143-198 https://doi.org/10.1615/CritRevTherDrugCarrierSyst.v15.i2.20

Roveri N, Bigi A, Castellani PP, Foresti E, Marchini M, Strocchi R (1980): Study of rat tail tendon by x-ray diffraction and freeze-etching technics. Boll. Della Soc. Ital. Biol. Sper. 56, 953-959

Schmidt-Wolf GD, Schmidt-Wolf IGH (2003): Non-viral and hybrid vectors in human gene therapy: an update. Trends Mol. Med. 9, 67-72 https://doi.org/10.1016/S1471-4914(03)00005-4

Uhríková D, Rapp G, Balgavý P (2002): Condensed lamellar phase in ternary DNA-DLPC-cationic gemini surfactant system: a small-angle synchrotron X-ray diffraction study. Bioelectrochemistry 58, 87-95 https://doi.org/10.1016/S1567-5394(02)00122-6

Uhríková D, Zajac I, Dubnicková M, Pisárcik M, Funari SS, Rapp G, Balgavý P (2005): Interaction of gemini surfactants butane-1,4-diyl-bis(alkyldimethylammonium bromide) with DNA. Colloids Surf. B Biointerfaces 42, 59-68 https://doi.org/10.1016/j.colsurfb.2005.02.002

Verma IM (2000): A tumultuous year for gene therapy. Mol. Ther. J. Am. Soc. Gene Ther. 2, 415-416 https://doi.org/10.1006/mthe.2000.0213

Wang C, Li X, Wettig SD, Badea I, Foldvari M, Verrall RE (2007): Investigation of complexes formed by interaction of cationic gemini surfactants with deoxyribonucleic acid. Phys. Chem. Chem. Phys. 9, 1616-1628 
https://doi.org/10.1039/b618579g

Wasungu L, Hoekstra D (2006): Cationic lipids, lipoplexes and intracellular delivery of genes. J. Controlled Release 116, 255-264 https://doi.org/10.1016/j.jconrel.2006.06.024

Wettig SD, Badea I, Donkuru M, Verrall RE, Foldvari M (2007): Structural and transfection properties of amine-substituted gemini surfactant-based nanoparticles. J. Gene Med. 9, 649-658 https://doi.org/10.1002/jgm.1060

Wiethoff CM, Gill ML, Koe GS, Koe JG, Middaugh CR (2003) A fluorescence study of the structure and accessibility of plasmid DNA condensed with cationic gene delivery vehicles. J. Pharm. Sci. 92, 1272-1285 https://doi.org/10.1002/jps.10391

Young ATL, Moore RB, Murray AG, Mullen JC, Lakey JRT (2004) Assessment of different transfection parameters in efficiency optimization. Cell Transplant. 13, 179-185 https://doi.org/10.3727/000000004773301861
Zabner J, Fasbender AJ, Moninger T, Poellinger KA, Welsh MJ (1995): Cellular and molecular barriers to gene transfer by a cationic lipid. J. Biol. Chem. 270, 18997-19007 https://doi.org/10.1074/jbc.270.32.18997

Zakharova LY, Gabdrakhmanov DR, Ibragimova AR, Vasilieva EA, Nizameev IR, Kadirov MK, Ermakova EA, Gogoleva NE, Faizullin DA, Pokrovsky AG, et al. (2016): Structural, biocomplexation and gene delivery properties of hydroxyethylated gemini surfactants with varied spacer length. Colloids Surf. B Biointerfaces 140, 269-277

https://doi.org/10.1016/j.colsurfb.2015.12.045

Zuhorn IS, Engberts JBFN, Hoekstra D (2007): Gene delivery by cationic lipid vectors: overcoming cellular barriers. Eur. Biophys. J. 36, 349-362 https://doi.org/10.1007/s00249-006-0092-4

Received: May 3, 2017

Final version accepted: September 18, 2017 


\section{Supplementary Material}

\section{DNA-DOPE-gemini surfactants complexes at low surface charge density: from structure to transfection efficiency}

Lukáš Hubčík ${ }^{1}$, Dominika Galliková ${ }^{1}$, Petra Pullmannová1,2, Lubica Lacinová ${ }^{3,4}, Z_{\text {dena Sulová }}$, Mária Hanulová ${ }^{\text {, Sergio S. Funari }}{ }^{6}$, Ferdinand Devínsky ${ }^{7}$ and Daniela Uhríková ${ }^{1}$

${ }^{1}$ Department of Physical Chemistry of Drugs, Faculty of Pharmacy, Comenius University in Bratislava, Odbojárov 10, 83232 Bratislava, Slovakia

${ }^{2}$ Department of Inorganic and Organic Chemistry, Faculty of Pharmacy in Hradec Králové, Charles University in Prague, Heyrovského 1203, 50005 Hradec Králové, Czech Republic

${ }^{3}$ Institute of Molecular Physiology and Genetics, Center of Biosciences, Slovak Academy of Sciences, Dubravska cesta 9, P.O.BOX 63, 84005 Bratislava, Slovakia

${ }^{4}$ Faculty of Natural Sciences, University of Ss. Cyril and Methodius, Nám. J. Herdu 2, 91701 Trnava, Slovakia

${ }^{5}$ Microscopy Core Facility at the Institute of Molecular Biology, Ackermannweg 4, 55128 Mainz, Germany

${ }^{6}$ HASYLAB at DESY, Notkestr. 85, D-22607 Hamburg, Germany

${ }^{7}$ Department of Chemical Theory of Drugs, Faculty of Pharmacy, Comenius University in Bratislava, Odbojárov 10, 83232 Bratislava, Slovakia

Small angle $X$-ray diffraction

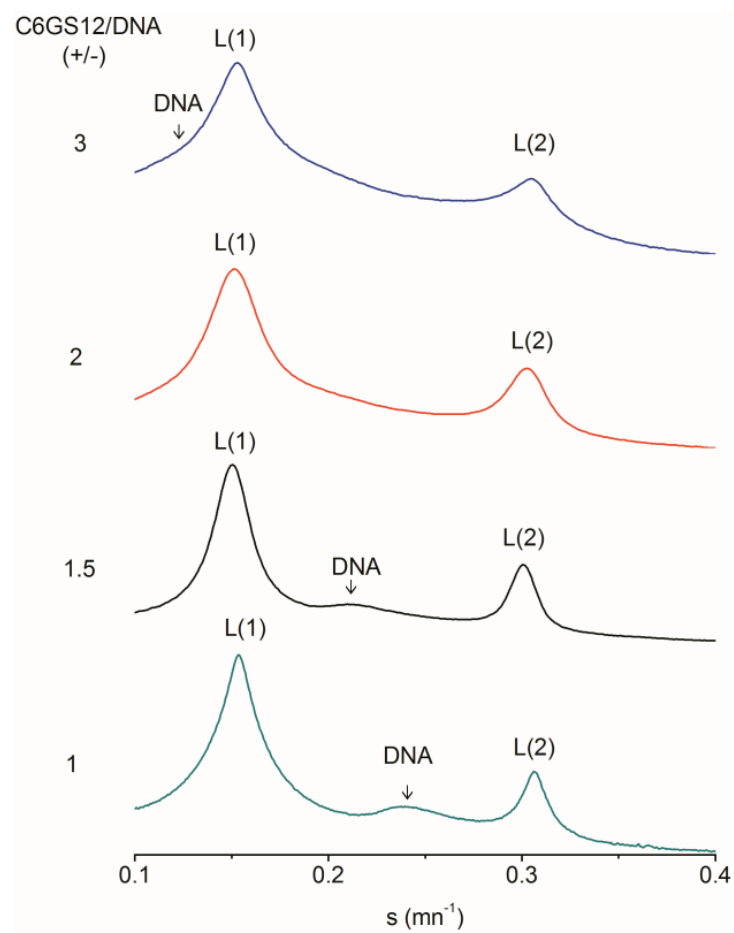

Figure S1. SAXD patterns of C6GS12/DOPE/DNA lipoplexes at molar ratio C6GS12/DOPE $=0.3$ and charge ratios C6GS12/DNA $=$ 1-3 hydrated by mixture of Opti-MEM and DMEM medium. The relative intensity is in logarithmic scale. 


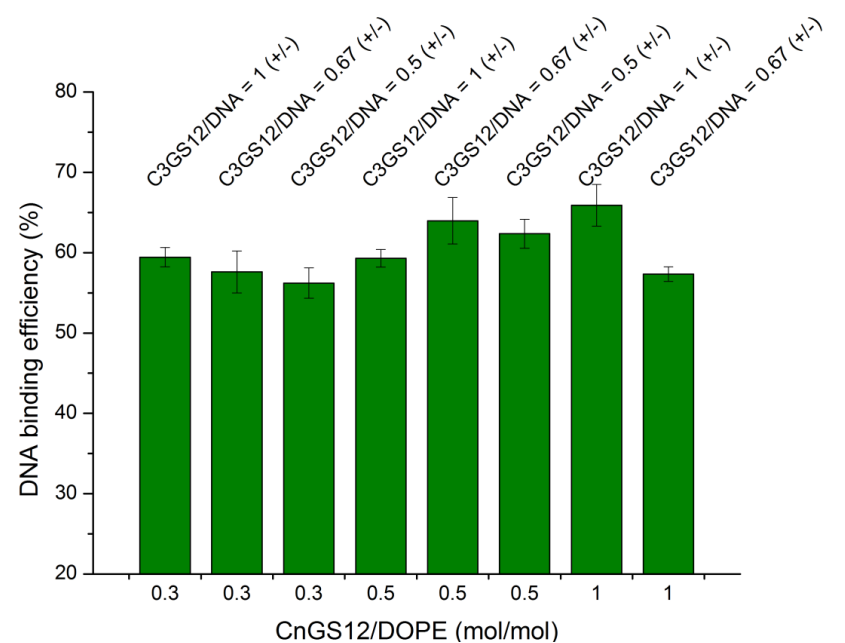

Figure S2. The DNA volume fraction bound by C3GS12/DOPE/ DNA lipoplexes prepared at various C3GS12/DOPE molar ratios and C3GS12/DNA charge ratios, hydrated by Opti-MEM and DMEM medium. Samples were measured $3 \mathrm{~h}$ after the preparation. The values of the DNA binding efficiency are related to the theoretical isoelectric point.

The capacity of C3GS12/DOPE/DNA lipoplexes for DNA binding

The volume fraction of DNA bound by C3GS12/DOPE liposomes was determined as the difference between the total DNA amount added to the sample and the DNA fraction non bound after the lipoplex formation. UV-VIS spectrophotometry was employed for quantitative analysis. The samples were measured twice, 3 hours (Figure S2) and in appr. 1 week (Figure S3) after the preparation. The scat-

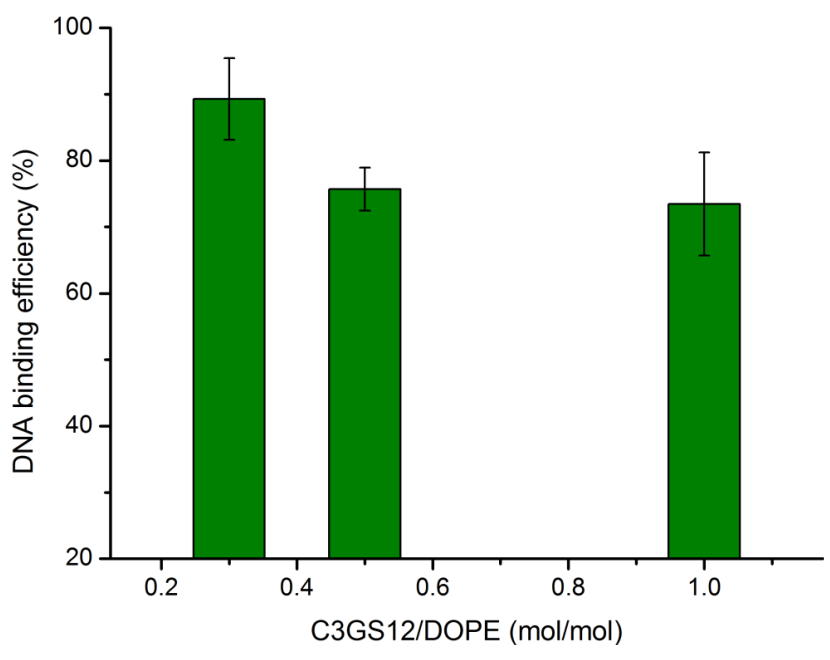

Figure S3. DNA volume fraction bound by C3GS12/DOPE/DNA lipoplexes prepared at various C3GS12/DOPE molar ratios and the charge ratio C3GS12/DNA $=1$, hydrated Opti-MEM and DMEM medium. Samples were measured $\sim 1$ week after the preparation.

tering on liposomes was corrected according to Lengyel et al. (2011).

\section{References}

Lengyel A, Uhríková D, Klacsová M, Balgavý P (2011): DNA condensation and its thermal stability influenced by phospholipid bilayer and divalent cations. Colloids Surf. B Biointerfaces 86, 212-217 https://doi.org/10.1016/j.colsurfb.2011.04.001 